possessing uricase, and hence in this property the anthropoids stand closer to man than to the monkeys, as they are also said to do in serological reactions. We have found a marsupial, the opossum, to have uricase, xanthine oxidase, guanase but no adenase. In respect to uric acid destruction our results agree perfectly with the urinary analyses of Hunter and others.

$$
96 \text { (9r3) }
$$

\title{
A quantitative application of the Abderhalden serum test.
}

\section{By Donald D. Van Slyke and Miriam Vinograd.}

[From the Hospital of the Rockefeller Institute for Medical Research, New York.]

The Abderhalden serum test can be greatly simplified, made quantitative, and the sensitiveness increased about thirty-fold compared with the dialysis test, by utilizing the nitrous acid method to detect proteolysis. The technique is the following: 2 c.c. of serum are digested with 0.1 gram of dried substrate (tissue prepared according to Abderhalden's directions and dried quickly at $0.5 \mathrm{~mm}$.), or, as nearly as can be estimated 0.4 gram of undried substrate. After the digestion is complete, 3 c.c. of water are added. The solution is then centrifugated, and 2 c.c. used for amino nitrogen determination in the micro-apparatus, 0.5 c.c. of caprylic alcohol being used to avoid foaming, and the reaction being run four minutes. Control analyses are run under the same conditions with serum that has been digested with normal tissue, and with no tissue. The amino method will detect one fourth the concentration of $\alpha-\mathrm{NH}_{2}$ that is apparent by the ninhydrin reaction, and the serum is diluted only one eighth as much in the above procedure as in the dialysis test, so that the sensitiveness is increased about thirty-fold. In spite of this, our results have been absolutely negative with the Rous chicken sarcomas Nos. I and 2 , even when serum tested was from the chicken furnishing the tissue substrate. The results do not, of course, bear on the validity of the test in human cases. We are about to test the method in human cancer and in pregnancy. The work on chicken tumors has been possible as a result of the cordial coöperation of Dr. Rous and Dr. Lange. 